\title{
KORELASI ANTARA POLA ASUH ORANG TUA DENGAN KEDISIPLINAN BELAJAR SISWA KELAS XI DI SMK MUDITA SINGKAWANG
}

\author{
Dian Mayasari ${ }^{1}$, Kamaruddin ${ }^{2}$, Siau Shiong ${ }^{3}$ \\ STKIP Singkawang, Singkawang, Indonesia \\ diansingkawang@gmail.com ${ }^{1}$, kamaruddin@yahoo.com ${ }^{2}$, siaushiong@gmail.com
}

\begin{tabular}{ll}
\hline \hline Kata Kunci : & ABSTRAK \\
Pola Asuh Orang Tua; & Penelitian ini bertujuan untuk mengetahui apakah ada korelasi \\
Kedisiplinan Belajar Siswa & antara pola asuh orang tua dengan kedisiplinan belajar siswa \\
& kelas XI di SMK Mudita Singkawang. Penelitian yang \\
& digunakan adalah penelitian kuantitatif dengan desain \\
& koefisien korelasi. Populasi dalam penelitian ini adalah siswa \\
& kelas XI SMK Mudita Singkawang, sebanyak 207 siswa. \\
& Pengambilan sampel menggunakan teknik simple random \\
& sampling, sebanyak 60 sampel. Metode pengumpulan data \\
menggunakan angket pola asuh orang tua dan angket \\
kedisiplinan belajar. Uji hipotesis dengan bantuan SPSS 24 \\
teknik korelasi Pearsons dengan taraf signifikansi O,05 dengan \\
nilai korelasional -,268 dan nilai sig. (2-tailed),038. Hasil \\
penelitian menyatakan terdapat korelasi antara pola asuh \\
orang tua dengan kedisiplinan belajar siswa kelas XI di SMK \\
Mudita Singkawang, maka Ha diterima dan HO ditolak.
\end{tabular}

\section{PENDAHULUAN}

Pola asuh orang tua merupakan proses interaksi yang terjadi antara orang tua terhadap anak dalam memberikan pengasuhan, didikan, serta bimbingan kepada anak untuk mencapai tugas perkembangan anak. Khon Mutadin (dalam Jannah, 2012) menyatakan pola asuh merupakan interaksi antara anak dan orangtua selama mengadakan kegiatan pengasuhan yang berarti orangtua mendidik, membimbing dan mendisiplinkan serta melindungi anak sehingga memungkinkan anak untuk mencapai tugas-tugas perkembangannya.

Baumrind (dalam Fellasari \& Lestari, 2017) mendefinisikan pola asuh sebagai pola sikap atau perlakuan orangtua terhadap remaja yang masing-masing mempunyai pengaruh tersendiri terhadap perilaku remaja antara lain terhadap kompetensi emosional, sosial, dan intelektual. Edwards \& Gunarsa (dalam Maliki, 2017) mendefinisikan pola asuh sebagai cara orang tua bertindak, berinteraksi, mendidik, dan membimbing anak sebagai suatu aktivitas yang melibatkan banyak perilaku tertentu secara individual maupun bersama- sama sebagai serangkaian usaha aktif untuk mengarahkan anak.

Pola asuh yang dibahas dalam penelitian yaitu pola asuh otoriter, demokratis dan laissez faire:

1) Authoritarian (otoriter)

Orang tua berlaku sangat ketat dan mengontrol anak dengan mengajarkan standar dan tingkah laku.

Pola asuh otoriter mengakibatkan kurangnya hubungan yang hangat dan komunikatif dalam keluarga. Anak dari pola asuh otoriter cenderung moody, murung, ketakutan, sedih, 
menggambarkan kecemasan dan rasa tidak aman dalam berhubungan dengan lingkungannya, menunjukkan kecenderungan bertindak keras saat tertekan dan memiliki harga diri yang rendah.

Pola asuh otoriter menetapkan standar yang mutlak harus dituruti, biasanya dibarengi dengan ancaman-ancaman misalnya, kalau tidak mau makan, maka tidak akan diajak bicara. Orang tua tipe otoriter cenderung memaksa, memerintah dan menghukum. Apabila anak tidak mau melakukan apa yang dikatakan oleh orang tua, maka orang tua tipe otoriter tidak segan menghukum anak. Orang tua tipe otoriter juga tidak mengenal kompromi dan dalam berkomunikasi biasanya bersifat satu arah. Ira Petranto (dalam Widiastuti \& Elshap, 2015).

2) Authoritative (demokratis)

Menurut Munandar (dalam Mawardi, 2016) pola asuh demokratis adalah cara mendidik anak, di mana orang tua menentukan peraturan-peraturan tetapi dengan memperhatikan keadaan dan kebutuhan anak. Sedangkan menurut Gunarsa (dalam Mawardi, 2016) pola asuh demokratis adalah suatu bentuk pola asuh yang memperhatikan dan menghargai kebebasan anak, namun kebebasan tersebut tidak mutlak dan dengan bimbingan yang penuh pengertian antara orang tua dan anak.

3) Laissez Faire

Menurut Danny I. Yatim-Irwanto (dalam Mawardi, 2016) pola asuhan laissez faire ditandai dengan adanya kebebasan tanpa batas pada anak untuk berperilaku sesuai dengan keinginannya sendiri. Orang tua tidak pernah memberi aturan dan pengarahan kepada anak. Semua keputusan diserahkan kepada anak tanpa pertimbangan orang tua. Anak tidak tahu apakah prilakunya benar atau salah karena orang tua tidak pernah membenarkan ataupun menyalahkan anak. Akibatnya anak akan berprilaku sesuai dengan keinginanya sendiri, tidak peduli apakah hal tersebut sesuai dengan norma masyarakat atau tidak.

Lingkungan keluarga merupakan lingkungan pertama yang dikenal oleh anak ketika lahir. Sehingga keluarga menjadi tempat dimana anak akan belajar untuk meniru hal-hal yang dilihat dan didengar, dengan begitu jelas bahwa pola asuh orang tua berpengaruh penting terhadap kedisiplinan belajar siswa, sehingga penerapan pola asuh orang tua dapat mempengaruhi kedisiplinan belajar siswa.

Kedisiplinan belajar merupakan kesadaran diri untuk melakukan pekerjaan dengan penuh tanggung jawab atas semua yang berhubungan dengan belajar. Setianingsih (2008) kedisiplinan belajar sebagai suatu sikap, tingkah laku dan perbuatan siswa untuk melakukan aktivitas belajar yang sesuai dengan keputusan-keputusan, peraturan-peraturan dan norma-norma yang telah ditetapkan bersama, baik persetujuan tertulis maupun tidak tertulis antara siswa dengan guru di sekolah maupun dengan orangtua di rumah untuk mendapatkan penguasaan pengetahuan, kecakapan, kebijaksanaan.

Prasojo (2014) menyampaikan kedisiplinan belajar adalah kadar atau derajat kepatuhan peserta didik terhadap peraturan-peraturan dan tata tertib sekolah untuk memperoleh kondisi yang lebih baik dengan menjadikan disiplin sebagai control penguasan diri yang dilakukan tanpa adanya paksaan. Singgih \& Pardiman (dalam Supardi, 2014) yang menyatakan bahwa disiplin belajar adalah pengendalian diri siswa terhadap bentuk-bentuk aturan baik secara tertulis maupun tidak tertulis yang telah diterapkan oleh siswa yang bersangkutan maupun berasal dari luar serta bentuk kesadaran akan tugas dan tanggung jawabnya sebagai pelajar.

Sulistiyowati (2001) agar seorang siswa dapat belajar dengan baik maka ia harus bersikap disiplin, terutama disiplin dalam hal-hal sebagai berikut: a) disiplin dalam menepati jadwal pelajaran. Bila seorang siswa mempunyai jadwal kegiatan belajar, ia harus menepati jadwal yang telah dibuatnya. Dalam hal ini jauh sebelumnya sudah di perintahkan untuk membuat jadwal belajar sesuai dengan jadwal pelajaran. b) disiplin dalam mengatasi godaan yang akan menunda waktu belajar. Bila seorang siswa sudah tiba waktunya untuk belajar kemudian diajak bermain oleh temannya, maka siswa tersebut harus dapat menolak ajakan temannya secara halus agar tidak tersinggung. c) disiplin terhadap 
diri sendiri, siswa dapat menumbuhkan semangat belajar baik di sekolah maupun dirumah. Sekalipun siswa mempunyai rencana belajar yang baik akan tetap tinggal rencana kalau tidak adanya disiplin diri. d) disiplin dalam menjaga kondisi fisik agar selalu sehat dan fit dengan caramakan makanan yang bergizi dan berolahraga secara teratur. Disiplin dalam menjaga kondisi fisik sangat penting, kalau tidak akan mempengaruhi aktivitas sehari-hari. Misalnya seorang siswa sebelum berangkat sekolah harus sarapan dulu agar dapat mengikuti kegiatan belajar dengan baik.

Arikunto ( dalam Sari \& Hadijah, 2017) mengemukakan macam-macam disiplin belajar ditunjukkan oleh beberapa perilaku yaitu, mentaati tata tertib sekolah, perilaku kedisiplinan di dalam kelas, disiplin dalam menepati jadwal belajar, dan belajar secara teratur. 2) Khalsa (dalam Maliki, 2017) mengemukakan ciri-ciri disiplin belajar yaitu (a) masuk kelas sesuai jadwal yang ditetapkan, (b) melakukan kegiatan di sekolah sesuai dengan petunjuk guru dan aturan sekolah, (c) melaksanakan piket kelas sebelum kegiatan belajar dimulai, (d) meminta izin jika berhalangan hadir mengikuti kegiatan belajar di sekolah, (e) menyapa guru dan teman saat bertemu, dan (f) mengikuti upacara tiap hari senin atau upacara hari nasional lainnya dengan tertib.

Pada sebagian sekolah disiplin belajar menjadi perhatian yang cukup penting. Hal ini dikarenakan masih banyak siswa yang memiliki sedikit kesadaran tentang pentingnya disiplin belajar. Kurangnya kesadaran untuk disiplin belajar pada siswa dapat dilihat ketika masih banyak siswa yang masih sering datang terlambat dan tidak mengerjakan tugas serta melanggar tata tertib yang berlaku di sekolah. Berdasarkan hasil wawancara guru Bimbingan dan Konseling dan observasi lapangan yang dilakukan di SMK Mudita Singkawang yang menyatakan bahwa masih ada sebagian siswa yang sering datang terlambat, meminta izin tidak masuk sekolah dengan mengatasnamakan nama orang tua dan melanggar tata tertib sekolah. Berdasarkan latar belakang yang ada maka akan dilakukan penelitian tentang Korelasi antara Pola Asuh Orang Tua dengan Kedisiplinan Belajar Siswa Kelas XI di SMK Mudita Singkawang.

\section{METODE}

Metode yang digunakan dalam penelitian ini adalah jenis kuantitatif dengan desain penelitian koefisien korelasi. Populasi penelitian ini adalah siswa siswi kelas XI SMK Mudita Singkawang tahun ajaran 2020/2021. Sampel dalam penelitian ini berjumlah 60 siswa yang diambil dengan teknik simple random sampling. Teknik pengumpulan data yang digunakan yaitu dengan menyebarkan angket. Penyebaran angket dengan menggunakan google form lewat link. Teknik pengumpulan data menggunakan rumus korelasi pearsons product moment.

\section{HASIL DAN PEMBAHASAN}

Penelitian dilakukan di SMK Mudita Singkawang, dengan jumlah populasi 207 siswa dan jumlah sampel 60 siswa. Tujuan penelitian ini adalah untuk melihat korelasi antara pola asuh orang tua dengan kedisiplinan belajar siswa kelas XI di SMK Mudita Singkawang. Pengolahan data menggunakan aplikasi SPSS versi 24. Sehingga didapatkanlah hasil seperti dibawah ini

Tabel 1. Korelasi Variabel $X$ dan Variabel $Y$

\section{Correlations}

\begin{tabular}{rrr|r} 
& & $\begin{array}{r}\text { Pola Asuh } \\
\text { Orang Tua }\end{array}$ & $\begin{array}{r}\text { Kedisiplinan } \\
\text { Belajar }\end{array}$ \\
\hline Pola Asuh & Pearson Correlation & 1 &,- 268 \\
\cline { 2 - 4 } Orang Tua & Sig. (2-tailed) & 60 &, 038 \\
\cline { 2 - 4 } & $\mathrm{N}$ & 60 & 60 \\
\hline Kedisiplinan & Pearson Correlation &,- 268 & 1 \\
Belajar & Sig. (2-tailed) &, 038 & \\
\cline { 2 - 4 } & $\mathrm{N}$ & 60 & 60 \\
\hline$*$. Correlation is significant at the 0.05 level (2-tailed).
\end{tabular}


Keterangan: Hasil Olah data SPSS Versi 24

Tabel diatas adalah hasil pengolahan data SPSS dari angket yang telah di isi oleh responden. Berdasarkan tabel di atas dapat dilihat bahwa nilai korelasional adalah -,268 dan nilai sig. (2-tailed) adalah ,038 dengan jumlah adalah 60 orang. Berdasarkan nilai korelasional -,268, maka hasil penelitian menyatakan koefisien korelasi negatif yang menunjukkan hubungan yang berbanding terbalik atau ketidak sejajaran, yaitu semakin tinggi pola asuh orang tua menunjukkan semakin rendah kedisiplinan belajar siswa, atau sebaliknya semakin rendah pola asuh orang tua menunjukkan semakin tinggi kedisiplinan belajar siswa.

Berdasarkan hasil penelitian diatas, maka dapat disimpulkan bahwa terdapat korelasi antara pola asuh orang tua dengan kedisiplinan belajar siswa kelas XI di SMk Mudita Singkawang. Adanya korelasi dapat dilihat dari nilai signifikansi yang kurang dari 0,05 sesuai dengan ketentuan pengambilan keputusan.

Dalam menyatakan tingkatan hubungan antara variabel $\mathrm{X}$ dan Variabel $\mathrm{Y}$ dapat dilihat melalui interpretasi nilai $\mathrm{r}$. Nilai korelasional hasil penelitian adalah -,268, jika dibandingkan dengan interpretasi nilai $\mathrm{r}$ maka hubungan antara pola asuh orang tua dengan kedisiplinan belajar adalah rendah serta arah hubungan antara kedua variabel menunjukkan arah hubungan negatif, yaitu apabila variabel $\mathrm{X}$ menunjukkan peningkatan maka variabel $\mathrm{Y}$ akan menunjukkan penurunan, begitu juga sebaliknya apabila variabel $\mathrm{X}$ menunjukkan penurunan maka variabel Y akan meningkat. Berdasarkan pernyataan diatas maka telah menjawab hipotesis penelitian yaitu Ha diterima, dan sekaligus menjawab rumusan masalah dalam penelitian ini yaitu terdapat hubungan antara pola asuh orang tua dengan kedisiplinan belajar siswa kelas XI di SMK Mudita Singkawang.

Hasil penelitian ini juga sejalan dengan Mufarokhah (2015) dengan judul penelitian Hubungan Pola Asuh Orang Tua Dengan Tingkat Kedisiplinan Siswa Kelas V MI AN-Nashriyah Kecamatan Lasem Kabupaten Rembang Tahun Ajaran 2014/2015, yang menunjukkan terdapat hubungan antara pola asuh orang tua dengan tingkat kedisiplinan siswa dengan kategori "cukup kuat'.

\section{KESIMPULAN DAN SARAN}

Kesimpulan

Berdasarkan hasil penelitian dan pembahasan mengenai korelasi antara pola asuh orang tua dengan kedisiplinan belajar siswa kelas XI di SMK Mudita Singkawang, maka dapat di simpulkan bahwa terdapat korelasi antara pola asuh orang tua dengan kedisiplinan belajar siswa kelas XI di SMK Mudita Singkawang.

Saran

Berdasarkan peneitian disarankan: (1) Guru Bimbingan dan Konseling dapat memberikan layanan informasi yang berhubungan dengan kedisiplinan belajar siswa. Misalnya pentingnya kedisiplinan belajar, dan penerapan kedisiplinan belajar di sekolah dan dirumah. (2) Agar siswa senantiasa dapat menerapkan kedisiplinan belajar, baik di sekolah maupun di rumah, dengan begitu dapat menjadi pribadi yang lebih baik, bertanggung jawab, disiplin dalam segala hal, serta memiliki akhlak yang mulia. (3) Agar peneliti selanjutnya dapat mengkaji lebih banyak sumber maupun referensi terkait variabel yang akan diteliti demi memperkaya kajian teori, serta dapat terus semangat dalam menyelesaikan penelitian. 


\section{DAFTAR PUSTAKA}

Fellasari, F., \& Lestari, Y. I. (2017). Hubungan Antara Pola Asuh Orangtua Dengan Kematangan Emosi Remaja. Jurnal Psikologi, 12(2), 84-90.

Jannah, H. (2012). Bentuk pola asuh orang tua dalam menanamkan perilaku moral pada anak usia di kecamatan ampek angkek. JURNAL ILMIAH PESONA PAUD, 1(2).

Maliki, M. (2017). Hubungan Pola Asuh Orang Tua terhadap Disiplin Belajar Siswa Di SMPN 7 Kubung. Jurnal Konseling dan Pendidikan, 5(1), 52-61.

Mawardi, S. (2016). Pola Pendidikan Kyai Abdul Malik Luqoni Pengasuh Pondok Pesantren Minhajut Thullab Sumberberas Muncar Banyuwangi. Jurnal Darussalam: Jurnal Pendidikan, Komunikasi dan Pemikiran Hukum Islam, 8(1), 95-114.

Mufarokhah, S. A. (2015). Hubungan pola asuh orang tua dengan tingkat kedisiplian siswa kelas V MI An-Nashriyah kecamatan Lasem kabupaten Rembang tahun ajaran 2014/2015 (Doctoral dissertation, UIN Walisongo).

Prasojo, R. J. (2014). Pengaruh Perhatian Orang Tua Dan Kedisiplinan Belajar Terhadap Prestasi Belajar Mata Pelajaran IPS. Ekonomi IKIP Veteran Semarang, 2(1), 37082.

Sari, B. P., \& Hadijah, H. S. (2017). Meningkatkan Disiplin Belajar Siswa melalui Manajemen Kelas. Jurnal Pendidikan Manajemen Perkantoran, 1(1), 124-131.

Setianingsih, D. (2008). Perbedaan kedisiplinan belajar siswa ditinjau dari pola asuh orangtua (Doctoral dissertation, Universitas Muhammadiyah Surakarta).

Sulistiyowati, (2001). Cara Belajar yang Efektif dan Efisien .Pekalongan:Cinta Ilmu.

Supardi, S. U. (2014). Peran kedisiplinan belajar dan kecerdasan matematis logis dalam pembelajaran matematika. Formatif: Jurnal Ilmiah Pendidikan MIPA, 4(2).

Widiastuti, N., \& Elshap, D. S. (2015). Pola Asuh Orang Tua Sebagai Upaya Menumbuhkan Sikap Tanggung Jawab pada Anak Dalam Menggunakan Teknologi Komunikasi. P2M STKIP Siliwangi, 2(2), 148-159. 